\title{
Transverse jointing in foreland fold-and-thrust belts: a remote sensing analysis in the eastern Pyrenees
}

\author{
Stefano Tavani ${ }^{1}$, Pablo Granado ${ }^{2}$, Amerigo Corradetti ${ }^{3}$, Thomas Seers ${ }^{3}$, Josep Maria Casas $^{4}$, and \\ Josep Anton Muñoz ${ }^{2}$ \\ ${ }^{1}$ DiSTAR, Università degli Studi di Napoli “Federico II”, Via Cupa Nuova Cintia 21, 80126, Naples, Italy \\ ${ }^{2}$ Institut de Recerca Geomodels, Departament de Dinàmica de la Terra i de l'Oceà, Universitat de Barcelona, \\ C/Martí i Franquès s/n 08028, Barcelona, Spain \\ ${ }^{3}$ Department of Petroleum Engineering, Texas A\&M University at Qatar, Education City, P.O. Box 23874, Doha, Qatar \\ ${ }^{4}$ Departament de Dinàmica de la Terra i de l'Oceà, Universitat de Barcelona, C/Martí i Franquès s/n, 08028, Barcelona, Spain
}

Correspondence: Stefano Tavani (stefano.tavani@unina.it)

Received: 28 April 2020 - Discussion started: 8 May 2020

Revised: 2 July 2020 - Accepted: 23 July 2020 - Published: 1 September 2020

\begin{abstract}
Joint systems in the eastern portion of the Ebro Basin of the eastern Pyrenees enjoy near continuous exposure from the frontal portion of the belt up to the external portion of its associated foredeep. Utilizing orthophoto mosaics of these world-class exposures, we have manually digitized over 30000 joints within a $16 \mathrm{~km} \times 50 \mathrm{~km}$ study area. The mapped traces exhibit orientations that are dominantly perpendicular to the trend of the belt (transverse) and, subordinately, parallel to the belt (longitudinal). In particular, joints systematically orient perpendicular to the trend of the belt both in the frontal folds and in the inner and central portion of the foredeep basin. Longitudinal joints occur rarely with a disordered spatial distribution, exhibiting null difference in abundance between the belt and the foredeep. Joint orientations in the external portion of the foredeep become less clustered, with adjacent areas dominated by either transverse or oblique joints. Our data indicate that joints in the studied area formed in the foredeep in response to a foredeepparallel stretching, which becomes progressively less intense within the external portion of the foredeep. There, the minimum stress direction becomes more variable, providing evidence of the poor contribution of the forebulge-perpendicular stretching on stress organization.
\end{abstract}

\section{Introduction}

Fractures can be effective pathways for fluid flow (e.g., Laubach et al., 2019), thus impacting the production of hydrocarbons (Barr et al., 2007; Engelder et al., 2009; Questiaux et al., 2010) and geothermal water (Haffen et al., 2013; Vidal et al., 2017), the pathways and fates of contaminants released from deep geological radioactive waste repositories (Berkowitz et al., 1988; Iding and Ringrose, 2010), and the sustainable management of groundwater (Masciopinto and Palmiotta, 2013). Associated with crustal tension, joints are ubiquitous open-mode fractures occurring in a range of tectonic settings, including collisional belts. In collisional settings, layer bending and stretching during the growth of thrust-related anticlines have conventionally been invoked as the principal causative process for the development of joints oriented approximately parallel (e.g., Ramsay, 1967; Murray, 1968) and perpendicular (e.g., Dietrich, 1989; Lemiszki et al., 1994) to the trend of the belt and of the thrust-related anticlines. However, the frequently observed obliquity between joints (and other mesoscale structures) and the trend of the hosting anticlines (e.g., Tavani et al., 2019; Beaudoin et al., 2020), along with the documented occurrence of joints in exposed forelands (e.g., Dunne and North, 1990; Zhao and Jacobi, 1997; Billi and Salvini, 2003; Whitaker and Engelder, 2006), has more recently led to the conclusion that, in many cases, joints and other kinds of extensional fractures exposed in thrust and fold belts developed prior to fold- 
ing and thrusting within the foreland region (e.g., Doglioni, 1995; Zhao and Jacobi, 1997; Tavarnelli and Peacock, 1999; Lash and Engelder, 2007; Branellec et al., 2015; Basa et al., 2019; Giuffrida et al., 2019; Martinelli et al., 2019; Carrillo et al., 2020), where joints are layer-perpendicular and commonly oriented parallel (longitudinal) and perpendicular (transverse) to the belt-foredeep-forebulge trend (Tavani et al., 2015).

A partially unresolved question in foreland deformation relates to the development of transverse joints, which requires a tensile minimum stress oriented parallel to the foredeep. Even in arched systems, the forebulge, the foredeep, and the belt tend to be nearly parallel to each other locally (e.g., the Hellenic arc, the Apennines-Calabrian arc, the Betic-Rif arc). The shortening direction in the inner portion of the foredeep (subjected to layer-parallel shortening) and the stretching direction in the forebulge (where bulgeperpendicular stretching induced by lithospheric outer arc extension operates) are nearly parallel in a belt-perpendicular transect (Fig. 1). In addition, in the innermost portion of the foredeep, where layer-parallel shortening operates, the $\sigma 2$ is typically vertical, and the $\sigma 3$ is positive, horizontal, and parallel to the trend of the belt (Tavani et al., 2015). Evidence of this is the occurrence of bedding-perpendicular pressure solution-vein pairs (e.g., Railsback and Andrews, 1995; Evans and Elmore, 2006; Quintà and Tavani, 2012; Weil and Yonkee, 2012) and/or conjugate strike-slip faults at a high angle to bedding (e.g., Marshak et al., 1982, Hancock, 1985; Erslev, 2001; Lacombe et al., 2006; Amrouch et al., 2010; Weil and Yonkee, 2012), which occur in foreland areas and in the adjacent fold-and-thrust belts worldwide, although in many cases structures associated with this strikeslip regime do not develop during layer-parallel shortening (e.g., Soliva et al., 2013). Given the above, there should be an area in between the inner portion of the foredeep and the peripheral bulge where $\sigma 1$ becomes vertical and where $\sigma 3$ is still horizontal and parallel to the belt (Fig. 1a). This scenario could explain the development of layer-perpendicular transverse extensional structures, with transverse extensional faults or veins expected to develop where $\sigma 3$ is positive. In this scenario, transverse joints occurring in this zone of localized tension could only develop as cross-joints (e.g., Gross, 1993) of the longitudinal set formed in the forebulge. This simplified model does not explain the documented occurrence of transverse joints in areas where longitudinal joints do not occur or represent the cross-joint set (e.g., Zhao and Jacobi, 1997; Quintà and Tavani, 2012). This framework does not admit a simple stress permutation in the foredeep and requires a negative (tensile) $\sigma 3$ connected to a foredeepparallel stretching component (Fig. 1b). Lithospheric bending of the foredeep, both along the horizontal plane (e.g., Doglioni, 1995) and along the vertical plane parallel to the trench (Quintà and Tavani, 2012), has been invoked as a process able to produce foredeep-parallel stretching.
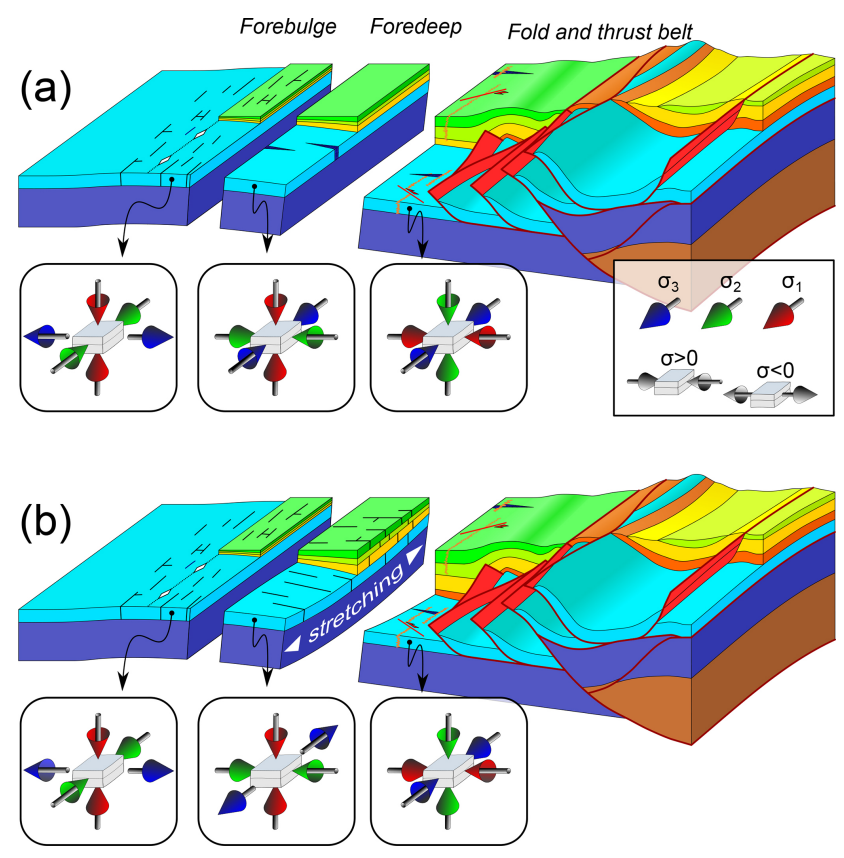

Figure 1. Scheme showing the architecture of a foreland fold-andthrust belt and adjacent foredeep basin with synorogenic fracture patterns in the different structural domains of the orogenic system. (a) The foredeep state of stress is governed by the permutation between the state of stress in the layer-parallel shortening and peripheral bulge domains. (b) The foredeep state of stress is controlled by the along-strike stretching of the foredeep.

Continuous exposures across the entire foreland region of the eastern Pyrenees allows for the investigation of the primary mechanism responsible for transverse joint development described above. Joints tens to hundreds of meters long affect the sedimentary sequence of the Ebro foredeep basin (Fig. 2a) and are found tilted within the frontal structures of the Pyrenean belt (Fig. 2b). These pre-folding joints are exceptionally exposed and mappable from orthophotos (Fig. 2c-f), from which they can be traced almost continuously from the external portion of the foredeep until the thrust belt. We have remotely mapped 30059 joint traces from the aforementioned orthophoto dataset and obtained their azimuthal distributions across the study area. Subsequently, this extended lineament database has been used to constrain the causative mechanism behind transverse jointing in the Ebro foredeep basin.

\section{Geological framework}

The study area is situated in the eastern Ebro foreland basin within an area connecting the eastern Pyrenees with the Catalan Coastal Range (Fig. 3a). The Pyrenees is an E-W striking orogenic system that formed as the Iberian and European plates collided from the late Cretaceous to Miocene times (Roest and Srivastava, 1991; Rosenbaum et al., 2002; 

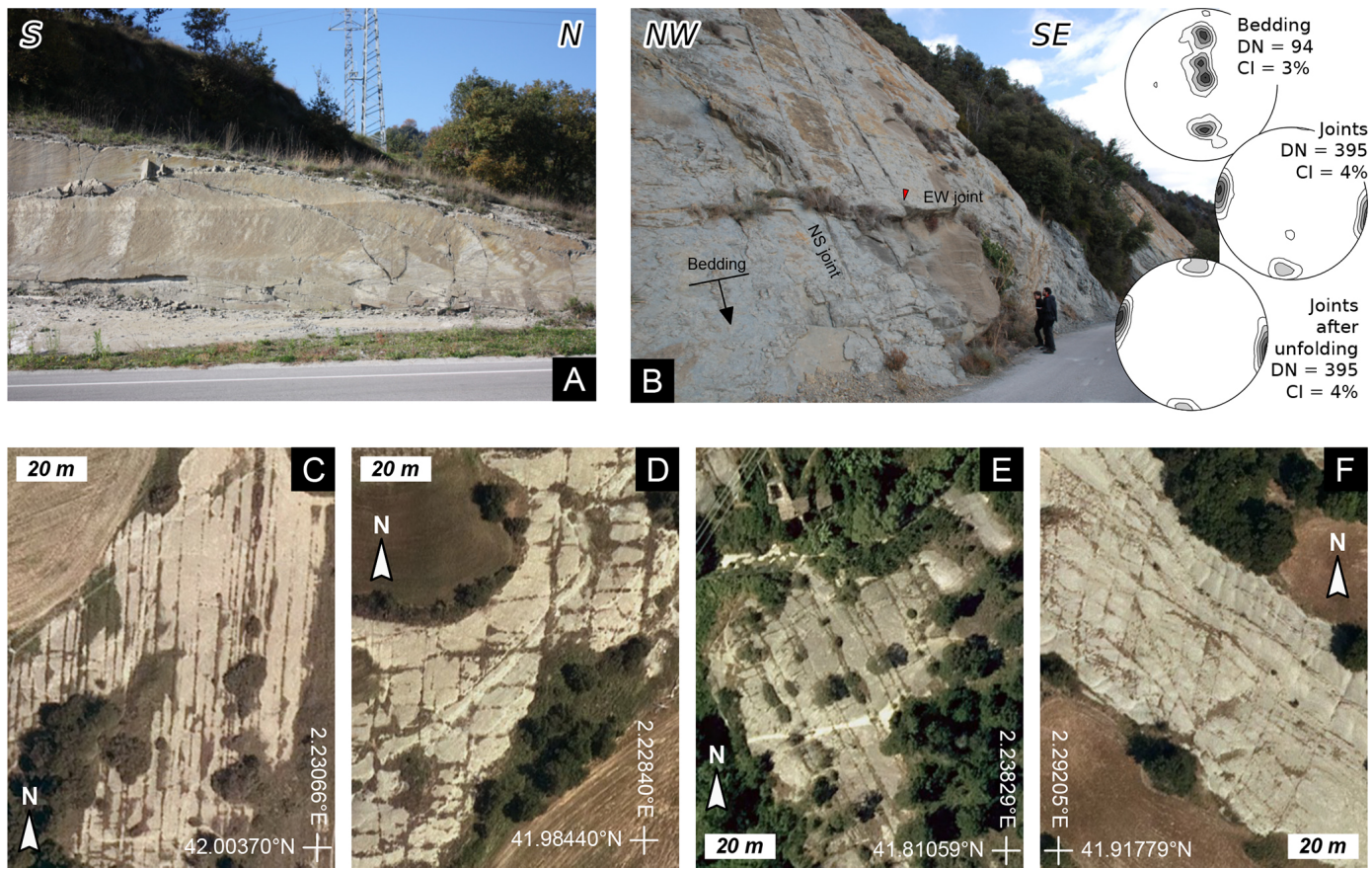

Figure 2. Examples of pre-folding joints within the studied area. (a) N-S striking joint with plumose structures in the foredeep sediments $\left(42^{\circ} 02^{\prime} 39.7^{\prime \prime} \mathrm{N}, 2^{\circ} 13^{\prime} 54.9^{\prime \prime} \mathrm{E}\right)$. (b) Tilted N-S and E-W striking joints in the southern limb of the Bellmunt anticline, with the red arrow indicating an E-W striking joint abutting on a N-S striking joint $\left(42^{\circ} 05^{\prime} 39^{\prime \prime} \mathrm{N}, 2^{\circ} 17^{\prime} 41.5^{\prime \prime} \mathrm{E}\right)$. The density contours of poles to bedding and joints (in their present-day orientation and after unfolding) refer to data collected in the Bellmunt anticline area. (c-f) Examples of joints seen in orthophotos. (c) Transverse joints. (d) N-S striking transverse joints with subordinate E-W striking cross-orthogonal joints. (e) NW-SE striking joints. (f) Rare example of multiple oblique sets occurring at the same exposure. The orthophotos in this figure are available from the Spanish Instituto Geográfico Nacional (https://pnoa.ign.es/, last access: 1 July 2020).

Muñoz, 1992, 2002), and it constitutes an asymmetric, doubly vergent orogenic wedge above the northward subduction of the Iberian lithosphere beneath the European plate (Chevrot et al., 2018). As a result, the Ebro Basin formed as a flexural foreland developed on the downgoing Iberian plate at the southern margin of the chain (Beaumont et al., 2000). In the study area, to the south of the Ebro Basin (Fig. 3a), the Catalan Coastal Range developed as a Paleogene intraplate left-lateral transpressional system (LópezBlanco, 2002; Santanach et al., 2011). The low-displacement character of thrusts and the absence of an associated foredeep both provide evidence of the limited importance of this range. A series of NE-SW and NW-SE trending extensional faults strike parallel and perpendicular to the Catalan Coastal Range, respectively, which are the result of the late Oligocene-Miocene opening of the NW Mediterranean basin (Vegas, 1992; Sàbat et al., 1995; Granado et al., 2016a).

The study area where joint traces have been digitized is delimited to the north by the frontal Pyrenean thrusts and by the Eocene Bellmunt anticline (Fig. 3a, b). This anticline comprises the Paleocene to upper Eocene foredeep infill. Immediately to the south of the anticline (i.e., $<5 \mathrm{~km}$ ), this multilayer becomes subhorizontal and thins southward where the Paleozoic to Mesozoic foredeep floor gently rises up and becomes exposed (Fig. 3a). There, this pre-orogenic succession is slightly tilted to the north by uplift in the footwall of the NW-SE striking late Oligocene to Neogene extensional faults. Further to the southwest, this succession is affected by the Paleogene contractional structures of the Catalan Coastal Range (Fig. 3b).

In the field, joints are constantly bedding-perpendicular regardless of the bedding dip (Fig. 2a, b), and they are characterized by the occurrence of either a single set (Fig. 2c) or a ladder pattern (Fig. 2d, e). In the latter case, the few E-W striking joints are almost everywhere perpendicular to the $\mathrm{N}$ $\mathrm{S}$ striking set and abut on it (Fig. 2e). This indicates that E-W striking joints are cross-joints formed perpendicular to, and nearly synchronous with, the $\mathrm{N}-\mathrm{S}$ striking joint set and that $\mathrm{N}-\mathrm{S}$ joints formed in response to a negative (tensile) minimum stress (e.g., Bai and Gross, 1999; Bai et al., 2002).

\section{Data and methods}

Joints have been digitized within the $16.4 \mathrm{~km} \times 49.2 \mathrm{~km}$ area displayed in Fig. 3 on 25 and $50 \mathrm{~cm} \mathrm{px}^{-1}$ orthophotos provided by the Spanish Instituto Geográfico Nacional via the PNOA (Plan Nacional de Ortofotografía Aérea) project (https://pnoa.ign.es/, last access: 1 July 2020). The open- 

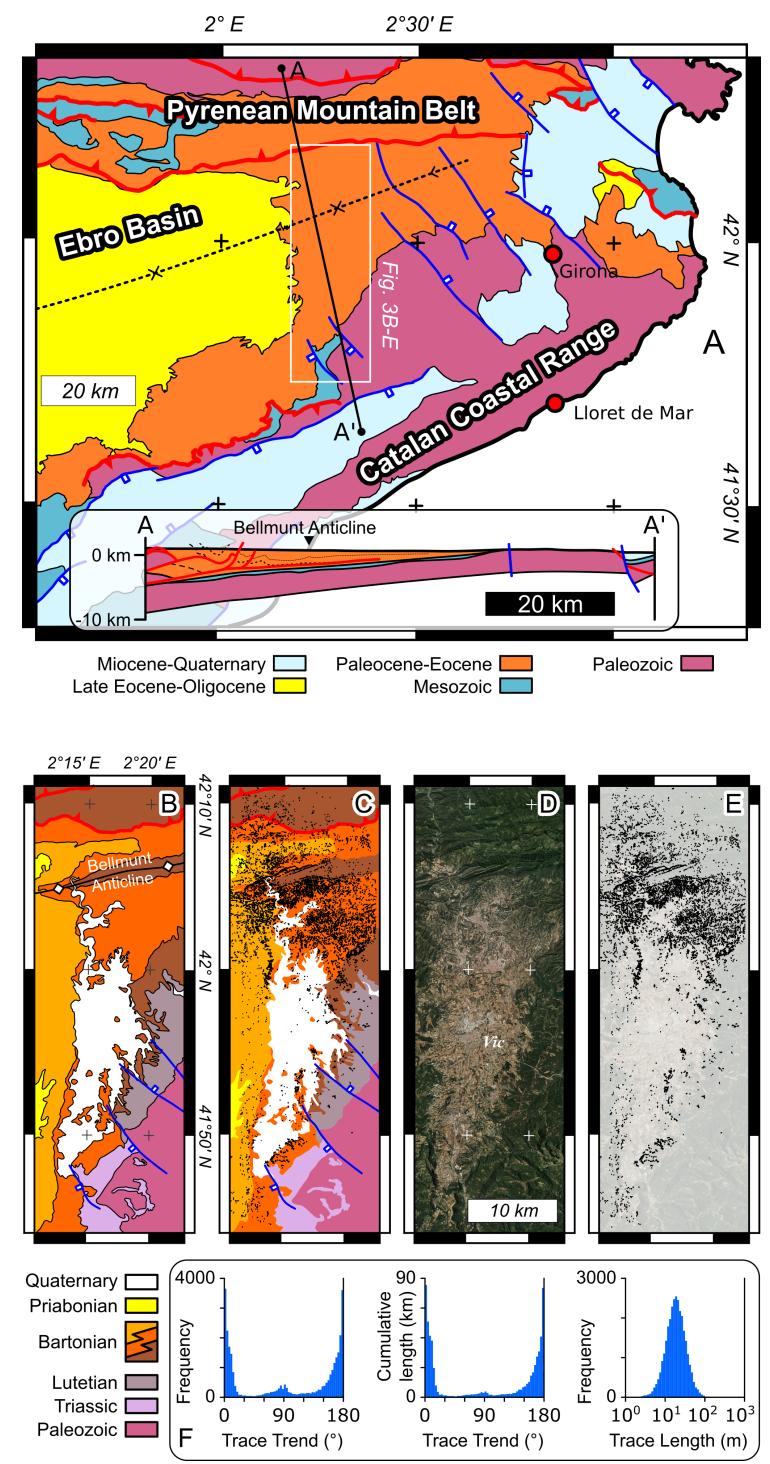

Figure 3. (a) Simplified geological map of the western Pyrenees and Catalan Coastal Range (based on the geological map of Catalonia scale 1:250000; https://www.icgc.cat/en/Downloads, last access: 1 July 2020) with the N-S geological cross section (modified from Parés et al., 1999). (b) Detailed geological map of the study area with digitized joints (c). (d) Orthophoto (https://pnoa.ign.es/, last access: 1 July 2020) of the study area with digitized joints (e). (f) Frequency distribution of joint traces trends and lengths.

source geographical information system QGIS 3.4 has been used to manually digitize 30059 joint traces. A collection of these traces seen in orthophotos is provided in Fig. 2c-f. Joints have been digitized from Bartonian and, subordinately, Lutetian and Priabonian sedimentary rocks (Fig. 3c). The NE and SE portions of the study area are highly vegetated (Fig. 3d, e), and only a few joint traces have been mapped there. Quaternary sediments unaffected by joints crop out in the central portion of the study area (Fig. 3d).
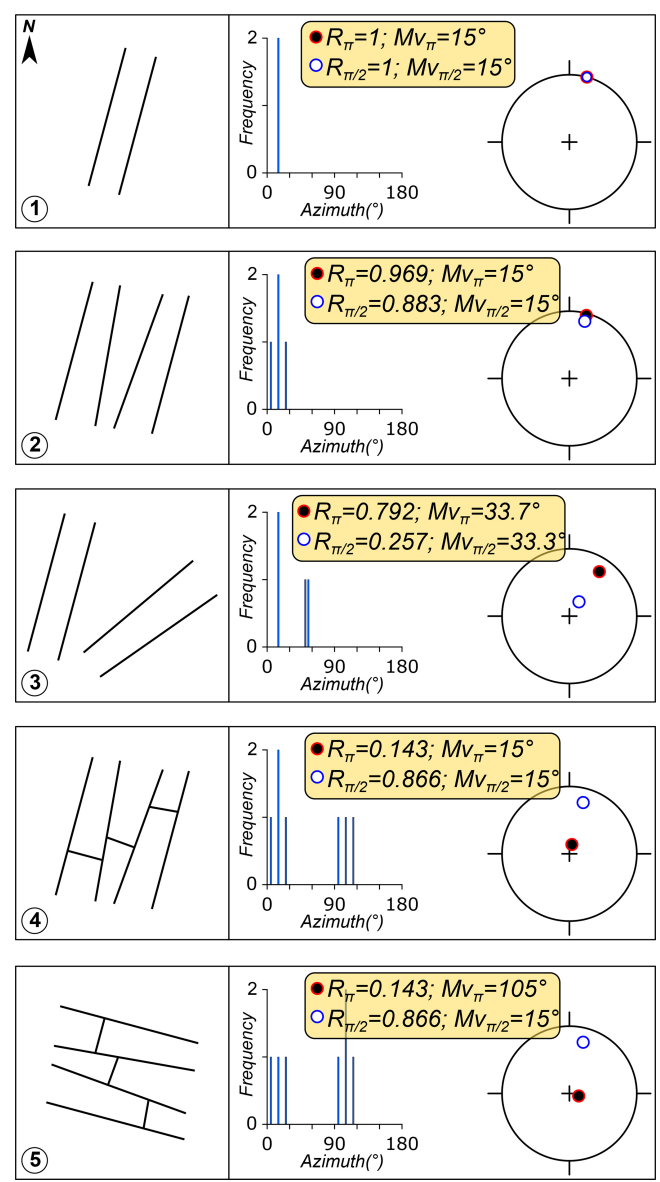

Figure 4. Examples of joint patterns and the resulting $\mathrm{Mv}$ and $R$ parameters calculated for the $\pi$ and $\pi / 2$ periods. For the five examples, we show the map view of the joints, the azimuthal frequency, and the sin-cos coordinates of the resulting values of $\mathrm{Mv}$ and $R$. Note that the distance from the center is proportional to $R$.

Digitized traces have lengths ranging from 2 to $100 \mathrm{~m}$ with an average of $\sim 20 \mathrm{~m}$ (Fig. 3f). The frequency distribution of the trace trend shows that the vast majority of the mapped joints is approximately N-S striking (Fig. 3f). A second subordinate set corresponds to E-W striking joints, which in the field occur as cross-joints (Fig. 2d). The frequency distribution of the trace trend is not symmetrical around these orthogonal sets due to the presence of a third less abundant set composed of NW-SE oriented joints (Fig. 2e, f). The NW-SE striking joints are mostly seen in the southern portion of the study area in exposures where the N-S striking set does not occur. As mentioned above, exposures are frequently characterized by a single set (Fig. 2c, d). At many locations, the dominant set is accompanied by associated cross-joints (Fig. 2d). Very rarely do two mutually oblique sets occur in the same exposure (Fig. 2f).

In order to evaluate the variability of joint traces, the $16.4 \mathrm{~km} \times 49.2 \mathrm{~km}$ study area has been divided into meshes of equilateral triangular elements with edge lengths of $1025 \mathrm{~m}$ 
(Mesh 1) and $1640 \mathrm{~m}$ (Mesh 2). At each node, the mean value and variance of trace trends have been computed using a circular moving window with a radius of $1200 \mathrm{~m}$ (Mesh 1) and $1900 \mathrm{~m}$ (Mesh 2). The radius of the circular moving window is set to these values for two reasons: (1) it is 2 orders of magnitude longer than the average length of joints and (2) it is large enough to ensure that most of the nodes have a data number $>20$ as only nodes with a data number $>20$ have been analyzed. Since trace trends are circular data with an angle $(\alpha)$ over a period of $180^{\circ}$, in agreement with Mardia (1975), we used equations 1 to 4 to derive at each node the circular mean value $\left(\mathrm{Mv}_{\pi}\right)$, the circular variance $\left(V_{\pi}\right)$, and the resultant length $\left(R_{\pi} ; V_{\pi}=1-R_{\pi}\right)$, the latter spanning from 0 (unclustered distribution) to 1 (perfectly clustered distribution). In the presence of cross-orthogonal joint sets, it is also useful using a period of $\pi / 2$, thus modifying Mardia's equations and introducing the $\mathrm{Mv}_{\pi / 2}$ and $R_{\pi / 2}$ parameters, which are computed using Eqs. (5) to (8).

$$
\begin{aligned}
& C_{\pi}=\frac{\sum_{i=1}^{n} \cos (2 \alpha)}{n} ; \\
& S_{\pi}=\frac{\sum_{i=1}^{n} \sin (2 \alpha)}{n} ; \\
& V_{\pi}=1-R_{\pi}=1-\sqrt{C_{\pi}^{2}+S_{\pi}^{2}} ; \\
& \mathrm{Mv}_{\pi}=\frac{\operatorname{Arctan}\left(S_{\pi} / C_{\pi}\right)}{2} ; \\
& C_{\pi / 2}=\frac{\sum_{i=1}^{n} \cos (4 \alpha)}{n} ; \\
& S_{\pi / 2}=\frac{\sum_{i=1}^{n} \sin (4 \alpha)}{n} ; \\
& V_{\pi / 2}=1-R_{\pi / 2}=1-\sqrt{C_{\pi / 2}^{2}+S_{\pi / 2}^{2}} ; \\
& \operatorname{Mv}_{\pi / 2}=\frac{\operatorname{Arctan}\left(S_{\pi / 2} / C_{\pi / 2}\right)}{2} .
\end{aligned}
$$

By using these four parameters together, instead of, for example, the classical $k$-means clustering analysis, it is possible to derive important considerations on the distribution of polymodal distributions in which two mutually orthogonal sets do occur, as illustrated in Fig. 4. In Fig. 4, we compare the Mv and the $R$ parameters computed using the $\pi$ and $\pi / 2$ periods. In the first example in Fig. 4, two parallel traces are analyzed, resulting in $\mathrm{Mv}_{\pi / 2}=\mathrm{Mv}_{\pi}$ and $R_{\pi / 2}=R_{\pi}=1$ (i.e., circular variance equals 0 ). When data dispersion is slightly increased (example 2 in Fig. 4), $\mathrm{Mv}_{\pi / 2}$ is still equal to $\mathrm{Mv}_{\pi}$, whereas $R_{\pi / 2}$ decreases faster than $R_{\pi}$. A further increase in data dispersion (example 3 in Fig. 4), in an asymmetric distribution (i.e., non-orthogonal sets), causes the additional decrease in $R_{\pi / 2}$ with respect to $R_{\pi}$ and a slight divergence between $\mathrm{Mv}_{\pi / 2}$ and $\mathrm{Mv}_{\pi}$. In the presence of a cross-orthogonal subset, the statistical usefulness of $R_{\pi / 2}$ becomes evident, as illustrated in example 4 in Fig. 4 . In this case, $R_{\pi}$ rapidly approaches 0 , suggesting high dispersion (i.e., unrepresentative $\mathrm{Mv}_{\pi}$ ), whereas $R_{\pi / 2}$ is essentially unaffected with respect to example 2 in Fig. 4, indicating low dispersion and a representative $M v_{\pi / 2}$. However, the use of the $\pi / 2$ period only returns results in the 0 to $\pi / 2$ range so that NW-SE trending traces result in a NE-SW trending mean value $\left(\mathrm{Mv}_{\pi / 2}\right)$, as shown in example 5 in Fig. 4. In summary, $\mathrm{Mv}_{\pi}$ is useful to derive the mean direction, whereas $R_{\pi / 2}$ and $R_{\pi}$ should be used in conjunction to discriminate populations in which oblique sets occur $\left(R_{\pi / 2}<R_{\pi}\right)$ from those in which two perpendicular sets occur $\left(R_{\pi / 2}>R_{\pi}\right)$.

\section{Results}

Figure 5 displays attribute maps generated from Mesh 1 and Mesh 2 using the trace orientation parameters described above. Both Mesh 1 and Mesh 2 have $R_{\pi}>0.5$ across almost the entire study area, with the only exception being in its NW corner. For $R_{\pi / 2}$, in addition to the NW corner, the central portion of the study area has $R_{\pi / 2}<0.5$. Noteworthy differences between $\mathrm{R}_{\pi}$ and $R_{\pi / 2}$ occur: (1) in the NW corner $\left(R_{\pi} \ll R_{\pi / 2}\right)$ and (2) in the central area $\left(R_{\pi} \gg R_{\pi / 2}\right)$. The first area corresponds to a vegetated folded and faulted zone (Fig. 3b-e). Consequently, we consider the dataset poorly reliable in this location. In the central portion of the study area, the difference between $R_{\pi}$ and $R_{\pi / 2}$ (which increases as data dispersion increases) is less pronounced in Mesh 1 than Mesh 2. Thus, data dispersion increases with the increasing search window size $(1200 \mathrm{~m}$ for Mesh 1 and $1900 \mathrm{~m}$ for Mesh 2), providing evidence that joint orientation is changing in this area. In the rest of the analyzed foreland, $R_{\pi / 2}$ has values similar to $R_{\pi}$, indicating an approximately unimodal data distribution within this region and the poor spatial organization of the longitudinal cross-joints.

Distribution of $\mathrm{Mv}_{\pi}$ relates to the prevalence of N-S striking joints in the northern and central portion of the study area. Towards the south, patches characterized by both $\mathrm{N}-$ $\mathrm{S}$ and NW-SE striking joints occur. High values of $R_{\pi}$ and $R_{\pi / 2}$ are characteristic of such subareas, which, as previously mentioned, is indicative of unimodal joint trace distributions.

\section{Discussion}

Remotely sensed and mapped joint traces in the eastern portion of the Pyrenees-Ebro system show systematic distributions of azimuthal orientations. In the frontal portion of the belt and within the foredeep, joints are mostly transverse (i.e., N-S striking) with a limited occurrence of E-W striking longitudinal cross-joints. Approaching the southern border of the foredeep, joints exhibit both N-S and NW-SE orientations where the pre-Cenozoic floor of the foredeep is exposed. Joints affect the Lutetian to Priabonian foredeep infill and are found tilted together with strata within the Bellmunt anticline (Fig. 2b), which is Priabonian in age (Burbank et al., 1992). Given the above, jointing in the study area must have taken place during or before the Priabonian. The occur- 

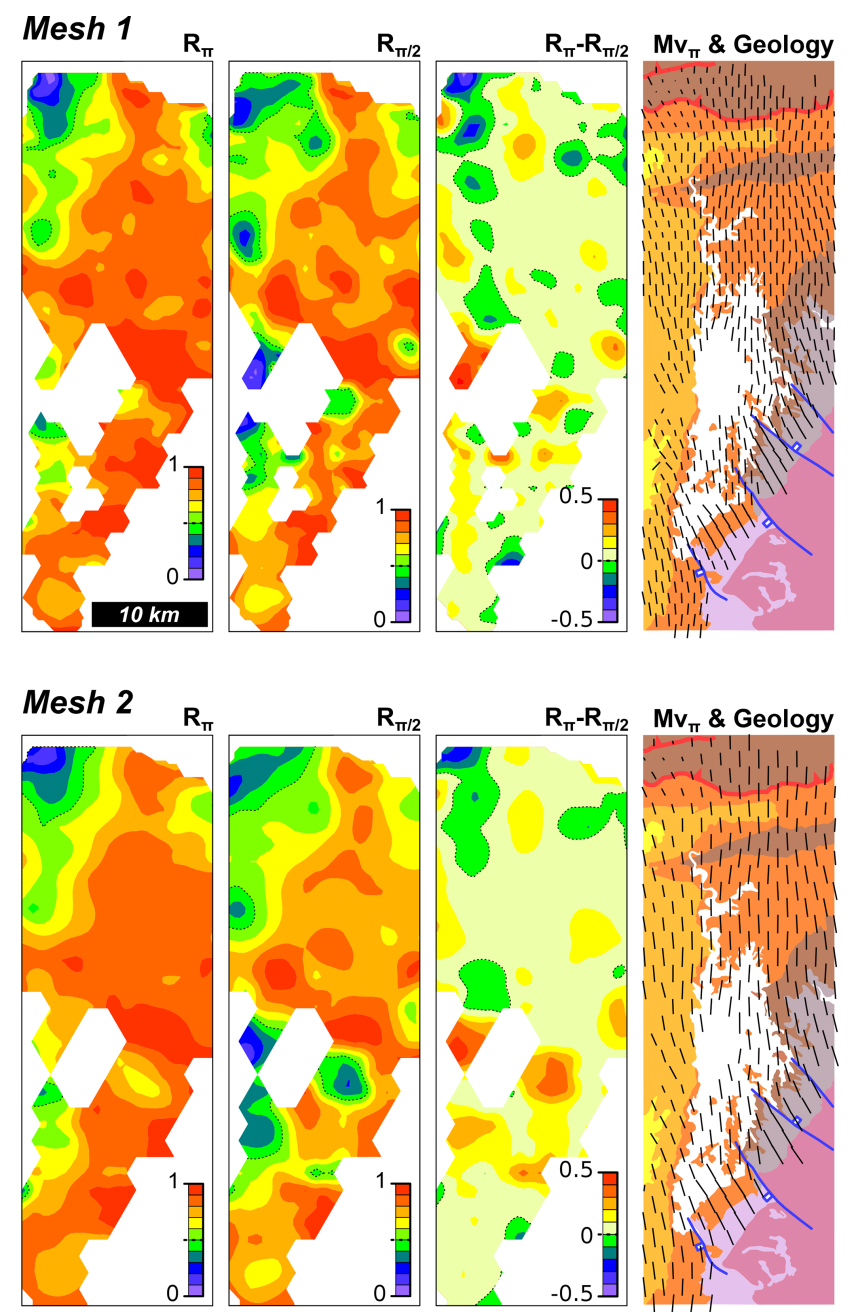

Figure 5. Results of circular statistics analysis for both meshes 1 and 2. Length of traces of $\mathrm{Mv}_{\pi}$ is proportional to $R_{\pi}$. Color code refers to $R_{\pi}$ and $R_{\pi / 2}$, whereas the orientation of traces is the Mv. See text for details.

rence of the N-S striking joints within the Ebro foredeep is documented also to the west of the study area (e.g., Turner and Hancock, 1990), where there are joint emplacement effects up to the Miocene (Arlegui and Simon, 2001). Transverse joints, striking approximately NNE-SSW, occur also to the SW in Bartonian to Priabonian strata cropping out at the boundary between the Ebro Basin and the Catalan Coastal Range (Alsaker et al., 1996). These data indicate that transverse joints systematically developed in the foredeep basin of the E-W oriented Pyrenean belt. Locally, the process of transverse jointing occurred until the early Miocene (i.e., until the end of mountain building). Also, pre-thrusting transverse extensional faults of upper Paleocene to lower Eocene age occur a few tens of kilometers to the NE of the study area (Carrillo et al., 2020), being presently incorporated in the Pyrenean belt. Thus, we conclude that foredeep-parallel tension has been established in the foredeep of the Pyre- nean belt from the Paleocene until the end of convergence. Transverse joints documented in this work clearly represent foredeep-related structures which can develop by (i) N-Soriented layer-parallel shortening (LPS) or (ii) E-W-oriented foredeep stretching (Tavani et al., 2015). LPS is to be excluded as the state of stress in this case would include a positive minimum stress (Fig. 1). In agreement, LPS-related extensional structures can form only due to fluid pressure contribution, and they include millimeter- to centimeter-long fractures filled with calcite (which is removed from pressure solution seams; Fig. 1; Tavani et al., 2015, and references therein). The type (joints with no calcite infill) and size (tens of meters long) of transverse extensional structures described here are incompatible with the layer-parallel shortening mechanism.

The relatively constant orientation of joints along the strike of the foredeep, the occurrence of appreciable dispersion at the outer border of the foredeep, and the remarkably poor number of longitudinal joints allow us to derive two major conclusions.

1. The almost linear trend of the eastern Pyrenees facilitates the exclusion of planar arching (e.g., Doglioni, 1995; Zhao and Jacobi, 1997) as the causative process for generating foredeep-parallel stretching (i.e., required to establish the negative $\sigma 3$ responsible for transverse jointing). Arching along the vertical plane parallel to the trench (Quintà and Tavani, 2012) instead represents a viable mechanism for generating alongforedeep stretching. This is analogous, albeit at a larger scale, to the process of release faulting described by Destro (1995). The basic concept behind this mechanism is the following: when a straight line joining two fixed points - the tips of a fault in the case of Destro (1995) or the edges of the foredeep in the case of Quintà and Tavani (2012) - becomes an arch, there is stretching (Fig. 1b) which causes extensional stress parallel to the direction of elongation. In essence, this mechanism is expected to operate in any doubly plunging foredeep particularly at its lateral edges, such as in the study area (Fig. 3a).

2. Extension in the peripheral bulge, which is documented from many active and inactive foredeep basins (e.g., Bradley and Kidd, 1991; Ranero et al., 2003; Tavani et al., 2015; Granado et al., 2016b), including the lower Eocene foredeep basin presently incorporated in the Pyrenees (e.g., Martinez et al., 1989; Pujadas et al., 1989), appears to be weakly influential at the southern border of the study area (i.e., the upper Eocene peripheral bulge). Indeed, the observed longitudinal joints are characteristically sub-ordered, forming locally as crossjoints to the identified transverse set within the study area (Fig. 2d). The transverse set becomes less organized at the southern margin of the foredeep, where patches of N-S- and NW-SE-dominated domains do 
occur. This provides evidence of the absence of a major forebulge-perpendicular extension capable of systematically reorienting $\sigma 3$ at the external foredeep edge.

\section{Conclusions}

The analysis of remotely sensed and mapped joints in the eastern Pyrenees and in the adjacent Ebro foreland basin indicates that the emplacement of the dominant joint set within the area, which strikes perpendicular to the trend of the foredeep, occurred prior to folding and developed in response to along-strike stretching caused by the plunging shape of the foredeep. Joints which developed in response to the flexuring of the lithosphere at the peripheral bulge do not occur in the area, suggesting that this mechanism has limited relevance to the observed joint system. This is confirmed by the variability of joint orientations observed at the foredeep external edge, negating the occurrence of a major forebulge-perpendicular extension able to systematically orient the stress field at the foredeep edge.

Data availability. Digitized traces in shapefile format and bedding and joint data in csv format are in the Supplement.

Supplement. The supplement related to this article is available online at: https://doi.org/10.5194/se-11-1643-2020-supplement.

Author contributions. ST, PG, and AC were responsible for conceptualization. ST and TS created the methodology. Data acquisition and analysis were performed by ST, PG, and JMC. Original draft preparation was carried out by ST, PG, and AC. Review and editing were carried out by TS and JAM. ST and JAM were responsible for project administration.

Competing interests. The authors declare that they have no conflict of interest.

Special issue statement. This article is part of the special issue "Faults, fractures, and fluid flow in the shallow crust". It is not associated with a conference.

Acknowledgements. We thank Roger Soliva, Eric Salomon, and an anonymous referee for useful suggestions. Institut de Recerca Geomodels and the Geodinàmica i Anàlisi de Conques research group (2014SGR467SGR) acknowledges financial support from the Agència de Gestió d'Ajuts Universitaris i de Recerca (AGAUR) and the Secretaria d'Universitats i Recerca del Departament d'Economia i Coneixement de la Generalitat de Catalunya.
Financial support. This research has been supported by the Ministerio de Ciencia, Innovación y Universidades/Agencia Estatal de Investigación/Fondo Europeo de Desarrollo Regional (grant nos. CGL2017-87631-P and PGC2018-093903-B-C22).

Review statement. This paper was edited by Roger Soliva and reviewed by Eric Salomon and one anonymous referee.

\section{References}

Alsaker, E., Gabrielsen, R. H., and Roca, E.: The significance of the fracture pattern of the Late-Eocene Montserrat fan-delta, Catalan Coastal Ranges (NE Spain), Tectonophysics, 266, 465-491, https://doi.org/10.1016/S0040-1951(96)00239-9, 1996.

Amrouch, K., Lacombe, O., Bellahsen, N., Daniel, J. M., and Callot, J. P.: Stress and strain patterns, kinematics and deformation mechanisms in a basement-cored anticline: Sheep Mountain Anticline, Wyoming, Tectonics, 29, TC1005, https://doi.org/10.1029/2009TC002525, 2010.

Arlegui, L. and Simón, J. L.: Geometry and distribution of regional joint sets in a non-homogeneous stress field: case study in the Ebro basin (Spain), J. Struct. Geol., 23, 297-313, https://doi.org/10.1016/S0191-8141(00)00097-3, 2001.

Bai, T. and Gross, M. R.: Theoretical analysis of cross-joint geometries and their classification, J. Geophys. Res.-Sol. Ea., 104, 1163-1177, https://doi.org/10.1029/1998JB900044, 1999.

Bai, T., Martin, L., Gross, M. R., and Aydin, A.: Orthogonal cross joints; do they imply a regional stress rotation?, J. Struct. Geol., 24, 77-88, https://doi.org/10.1016/S01918141(01)00050-5, 2002.

Barr, D., Savory, K. E., Fowler, S. R., Arman, K., and McGarrity, J. P.: Pre-development fracture modelling in the Clair field, west of Shetland, Geol. Soc. Lond. Spec. Publ., 270, 205-225, https://doi.org/10.1144/GSL.SP.2007.270.01.14, 2007.

Basa, A., Ahmed, F., Bhattacharyya, K., and Roy, A.: Evolution and characterization of fracture patterns: Insights from multi-scale analysis of the Buxa dolomite in the Siang Valley, Arunachal Lesser Himalayan fold-thrust belt, J. Struct. Geol., 123, 54-66, https://doi.org/10.1016/j.jsg.2019.03.004, 2019.

Beaumont, C., Muñoz, J. A., Hamilton, J., and Fullsack, P.: Factors controlling the Alpine evolution of the central Pyrenees inferred from a comparison of observations and geodynamical models, J. Geophys. Res.-Sol. Ea., 105, 8121-8145, https://doi.org/10.1029/1999JB900390, 2000.

Beaudoin, N., Lacombe, O., David, M.-E., and Koehn, D. Does stress transmission in forelands depend on structural style?. Distinctive stress magnitudes during Sevier thinskinned and Laramide thick-skinned layer-parallel shortening in the Bighorn Basin (USA) revealed by stylolite and calcite twinning paleopiezometry, Terra Nova, 32, 225-233, https://doi.org/10.1111/ter.12451, 2020.

Berkowitz, B., Bear, J., and Braester, C.: Continuum models for contaminant transport in fractured porous formations, Water Resour. Res., 24, 1225-1236, https://doi.org/10.1029/WR024i008p01225, 1988.

Billi, A. and Salvini, F.: Development of systematic joints in response to flexure-related fibre stress in flexed foreland plates: the 
Apulian forebulge case history, Italy, J. Geodyn., 36, 523-536, https://doi.org/10.1016/S0264-3707(03)00086-3, 2003.

Bradley, D. C. and Kidd, W. S. F.: Flexural extension of the upper continental crust in collisional foredeeps, Geol. Soc. Am. Bull., 103, 1416-1438, https://doi.org/10.1130/00167606(1991)103<1416:FEOTUC>2.3.CO;2, 1991.

Branellec, M., Callot, J. P., Nivière, B., and Ringenbach J. C.: The fracture network, a proxy for mesoscale deformation: Constraints on layer parallel shortening history from the Malargüe fold and thrust belt, Argentina, Tectonics, 34, 623-647, https://doi.org/10.1002/2014TC003738, 2015.

Burbank, D. W., Puigdefàbregas, C., and Muñoz, J. A.: The chronology of the Eocene tectonic and stratigraphic development of the eastern Pyrenean foreland basin, northeast Spain, Geol. Soc. Am. Bull., 104, 1101-1120, https://doi.org/10.1130/00167606(1992)104<1101:TCOTET>2.3.CO;2, 1992.

Carrillo, E., Guinea, A., Casas, A., Rivero, L., Cox, N., and Vázquez-Taset, Y. M.: Tectono-sedimentary evolution of transverse extensional faults in a foreland basin: Response to changes in tectonic plate processes, Basin Res., https://doi.org/10.1111/bre.12434, online first, 2020.

Chevrot, S., Sylvander, M., Díaz, J., Martin, R., Mouthereau, F., Manatschal, G., Masini, E., Calassou, S., Grimaud, F., Pauchet, H., and Ruiz, M.: The non-cylindrical crustal architecture of the Pyrenees, Sci. Rep.-UK, 8, 9591, https://doi.org/10.1038/s41598-018-27889-x, 2018.

Destro, N.: Release fault: A variety of cross fault in linked extensional fault systems, in the Sergipe-Alagoas Basin, NE Brazil, J. Struct. Geol., 17, 615-629, https://doi.org/10.1016/01918141(94)00088-H, 1995.

Dietrich, D.: Fold-axis parallel extension in an arcuate fold-and thrust belt: the case of the Helvetic nappes, Tectonophysics, 170, 183-212, https://doi.org/10.1016/0040-1951(89)90271-0, 1989.

Doglioni, C.: Geological remarks on the relationships between extension and convergent geodynamic settings, Tectonophysics, 252, 253-267, https://doi.org/10.1016/0040-1951(95)00087-9, 1995.

Dunne, W. M. and North, C. P.: Orthogonal fracture systems at the limits of thrusting: an example from southwestern Wales, J. Struct. Geol., 12, 207-215, https://doi.org/10.1016/01918141(90)90005-J, 1990.

Engelder, T., Lash, G. G., and Uzcategui, R.: Joint sets that enhance production from Middle-Upper Devonian gas shales of the Appalachian basin, AAPG Bull., 93, 857-889, https://doi.org/10.1306/03230908032, 2009

Erslev, E. A.: Multistage, multidirectional Tertiary shortening and compression in north-central New Mexico, B. Geol. Soc. Am., 113, 63-74, https://doi.org/10.1130/00167606(2001)113<0063:MMTSAC>2.0.CO;2, 2001.

Evans, M. A. and Elmore, R. D.: Fluid control of localized mineral domains in limestone pressure solution structures, J. Struct. Geol., 28, 284-301, https://doi.org/10.1016/j.jsg.2005.10.004, 2006.

Giuffrida, A., La Bruna, V., Castelluccio, P., Panza, E., Rustichelli, A., Tondi, E., Giorgioni, M., and Agosta, F.: Fracture simulation parameters of fractured reservoirs: Analogy with outcropping carbonates of the Inner Apulian Platform, southern Italy, J. Struct. Geol., 123, 18-41, https://doi.org/10.1016/j.jsg.2019.02.007, 2019.
Granado, P., Urgeles, R., Sábat, F., Albert-Villanueva, E., Roca, E., Muñoz, J. A., Mazzucca, N., and Gambini, R.: Geodynamical framework and hydrocarbon plays of a salt giant: the North Western Mediterranean Basin, Petrol. Geosci., 22, 309321, https://doi.org/10.1144/petgeo2015-084, 2016a.

Granado, P., Thöny, W., Carrera, N., Gratzer, O., Strauss, P., and Muñoz, J. A.: Basement-involved reactivation in fold and thrust belts: the Alpine-Carpathian Junction (Austria), Geol. Mag., 153, 1100-1135, https://doi.org/10.1017/S0016756816000066, 2016b.

Gross, M. R.: The origin and spacing of cross joints: examples from the Monterey Formation, Santa Barbara Coastline, California, J. Struct. Geol., 15, 737-751, https://doi.org/10.1016/01918141(93)90059-J, 1993.

Haffen, S., Géraud, Y., Diraison, M., and Dezayes, C.: Determination of fluid-flow zones in a geothermal sandstone reservoir using thermal conductivity and temperature logs, Geothermics, 46, 3241, https://doi.org/10.1016/j.geothermics.2012.11.001, 2013.

Hancock, P. L.: Brittle microtectonics: principles and practice, J. Struct. Geol., 7, 437-457, https://doi.org/10.1016/01918141(85)90048-3, 1985.

Iding, M. and Ringrose, P.: Evaluating the impact of fractures on the performance of the In Salah $\mathrm{CO}_{2}$ storage site, Int. J. Greenh. Gas Con., 4, 242-248, https://doi.org/10.1016/j.ijggc.2009.10.016, 2010.

Lash, G. G. and Engelder, T.: Jointing within the outer arc of a forebulge at the onset of the Alleghanian Orogeny, J. Struct. Geol., 29, 774-786, https://doi.org/10.1016/j.jsg.2006.12.002, 2007.

Lacombe, O., Mouthereau, F., Kargar, S., and Meyer, B.: Late Cenozoic and modern stress fields in the western Fars (Iran): implications for the tectonic and kinematic evolution of central Zagros, Tectonics, 25, TC1003, https://doi.org/10.1029/2005TC001831, 2006.

Laubach, S. E., Lander, R. H., Criscenti, L. J., Anovitz, L. M., Urai, J. L., Pollyea, R. M., Hooker , J. N., Narr , W., Evans, M. A., Kerisit , S. N., Olson, S. N., Dewers, T., Fisher, D., Bodnar, R., Evans, B., Dove, P., Bonnell, L. M., Marder, M. P., and Pyrak-Nolte, M. P.: The role of chemistry in fracture pattern development and opportunities to advance interpretations of geological materials, Rev. Geophys., 57, 1065-1111, https://doi.org/10.1029/2019RG000671, 2019.

Lemiszki, P. J., Landes, J. D., and Hatcher, R. D.: Controls on hinge-parallel extension fracturing in single-layer tangentiallongitudinal strain folds, J. Geophys. Res.-Sol. Ea., 99, 22027 22041, https://doi.org/10.1029/94JB01853, 1994.

López-Blanco, M.: Sedimentary response to thrusting and fold growing on the SE margin of the Ebro basin (Paleogene, NE Spain), Sediment. Geol., 146, 133-154, https://doi.org/10.1016/S0037-0738(01)00170-1, 2002.

Mardia, K. V.: Statistics of directional data, J. R. Stat. Soc. B, 37, 349-393, 1975.

Marshak, S., Geiser, P. A., Alvarez, W., and Engelder, T.: Mesoscopic fault array of the northern Umbrian Apennine fold belt, Italy: geometry of conjugate shear by pressure-solution slip, Geol. Soc. Am. Bull., 93, 1013-1022, https://doi.org/10.1130/00167606(1982)93<1013:MFAOTN>2.0.CO;2, 1982

Martinelli, M., Bistacchi, A., Balsamo, F., and Meda, M.: Late Oligocene to Pliocene extension in the Maltese Is- 
lands and implications for geodynamics of the Pantelleria Rift and Pelagian Platform, Tectonics, 38, 3394-3415, https://doi.org/10.1029/2019TC005627, 2019.

Martinez, A., Verges, J., Clavell, E., and Kennedy, J.: Stratigraphic framework of the thrust geometry and structural inversion in the southeastern Pyrenees: La Garrotxa Area, Geodin. Acta, 3, 185194, https://doi.org/10.1080/09853111.1989.11105185, 1989.

Masciopinto, C. and Palmiotta, D.; Flow and transport in fractured aquifers: new conceptual models based on field measurements, Transport Porous Med., 96, 117-133, https://doi.org/10.1007/s11242-012-0077-y, 2013.

Muñoz, J. A.: Evolution of a continental collision belt: ECORSPyrenees crustal balanced cross-section, in: Thrust Tectonics, edited by: McClay, K., Chapman \& Hall, London, 235-246, 1992.

Muñoz, J. A.: The Pyrenees, in: The Geology of Spain, edited by: Gibbons, W. and Moreno, M. T., 370-385, Geological Society, London, UK, 2002.

Murray Jr., G. H.: Quantitative fracture study - Sanish pool, McKenzie County, North Dakota, AAPG Bull., 52, 57-65, 1968.

Parés, J. M., van der Pluijm, B. A., and Dinarès-Turell, J.: Evolution of magnetic fabrics during incipient deformation of mudrocks (Pyrenees, northern Spain), Tectonophysics, 307, 1-14, https://doi.org/10.1016/S0040-1951(99)00115-8, 1999.

Pujadas, J., Casas, J. M., Muñoz, J. A., and Sábat, F.: Thrust tectonics and paleogene syntectonics sedimentation in the Empordà area, southeatern Pyrenees, Geodin. Acta, 3, 195-206, https://doi.org/10.1080/09853111.1989.11105186, 1989.

Questiaux, J.-M., Couples, G. D., and Ruby, N.: Fractured reservoirs with fracture corridors, Geophys. Prospect., 58, 279-295, https://doi.org/10.1111/j.1365-2478.2009.00810.x, 2010.

Quintà, A. and Tavani, S.: The foreland deformation in the southwestern Basque-Cantabrian Belt (Spain), Tectonophysics, 576, 4-19, https://doi.org/10.1016/j.tecto.2012.02.015, 2012.

Ramsay, J. G.: Folding and Fracturing of Rocks, McGraw-Hill Book Company, Inc., New York, 568 pp., 1967.

Railsback, B. L. and Andrews, L. M.: Tectonic stylolites in the "undeformed" Cumberland Plateau of southern Tennessee, J. Struct. Geol., 17, 911-915, https://doi.org/10.1016/01918141(94)00127-L, 1995.

Ranero, C. R., Morgan, J. P., McIntosh, K., and Reichert, C.: Bending-related faulting and mantle serpentinization at the Middle America trench, Nature, 425, 367-373, https://doi.org/10.1038/nature01961, 2003.

Roest, W. R. and Srivastava, S. P.: Kinematics of the plate boundaries between Eurasia, Iberia, and Africa in the North Atlantic from the Late Cretaceous to the present, Geology, 19, 613-616, https://doi.org/10.1130/00917613(1991)019<0613:KOTPBB>2.3.CO;2, 1991.

Rosenbaum, G., Lister, G. S., and Duboz, C.: Reconstruction of the tectonic evolution of the western Mediterranean since the Oligocene, Journal of the Virtual Explorer, 8, 107-130, 2002.

Sàbat, F., Roca, E., Muñoz, J. A., Vergés, J., Sans, M., Masana, E., Santanach, P., Estévez, A., and Santisteban, C.: Role of extension and compression in the evolution of the eastem margin of Iberia: the ESCI-València Trough seismic profile, Rev. Soc. Esp. Geol., 8, 431-448, 1995.
Santanach, P., Casas, J. M., Gratacós, O., Liesa, M., Muñoz, J. A., and Sàbat, F.: Variscan and Alpine structure of the hills of Barcelona: geology in an urban area, J. Iber. Geol., 37, 121-136, https://doi.org/10.5209/rev_JIGE.2011.v37.n2.2, 2011.

Soliva, R., Schultz, R. A., Ballas, G., Taboada, A., Wibberley, C., Saillet, E., and Benedicto, A.: A model of strain localization in porous sandstone as a function of tectonic setting, burial and material properties; new insight from Provence (southern France), J. Struct. Geol., 49, 50-63, https://doi.org/10.1016/j.jsg.2012.11.011, 2013.

Tavani, S., Storti, F., Lacombe, O., Corradetti, A., Muñoz, J. A., and Mazzoli, S.: A review of deformation pattern templates in foreland basin systems and fold-and-thrust belts: Implications for the state of stress in the frontal regions of thrust wedges. Earth-Sci. Rev., 141, 82-104, https://doi.org/10.1016/j.earscirev.2014.11.013, 2015.

Tavani, S., Corradetti, A., De Matteis, M., Iannace, A., Mazzoli, S., Castelluccio, A., Spanos, D., and Parente, M.: Early-orogenic deformation in the Ionian zone of the Hellenides: Effects of slab retreat and arching on syn-orogenic stress evolution, J. Struct. Geol., 124, 168-181, https://doi.org/10.1016/j.jsg.2019.04.012, 2019.

Tavarnelli, E. and Peacock, D. C.: From extension to contraction in syn-orogenic foredeep basins: the Contessa section, Umbria-Marche Apennines, Italy, Terra Nova, 11, 55-60, https://doi.org/10.1046/j.1365-3121.1999.00225.x, 1999.

Turner, J. P., and Hancock, P. L.: Relationships between thrusting and joint systems in the Jaca thrust-top basin, Spanish Pyrenees, J. Struct. Geol., 12, 217-226, https://doi.org/10.1016/01918141(90)90006-K, 1990.

Vegas, R.: The Valencia Trough and the origin of the western Mediterranean basins, Tectonophysics, 203, 249-261, 1992.

Vidal, J., Genter, A., and Chopin, F.: Permeable fracture zones in the hard rocks of the geothermal reservoir at Rittershoffen, France, J. Geophys. Res.-Sol. Ea., 122, 4864-4887, https://doi.org/10.1002/2017JB014331, 2017.

Weil, A. B. and Yonkee, W. A.: Layer-parallel shortening across the Sevier fold-thrust belt and Laramide foreland of Wyoming: spatial and temporal evolution of a complex geodynamic system, Earth Planet. Sc. Lett., 357, 405-420, https://doi.org/10.1016/j.epsl.2012.09.021, 2012.

Whitaker, A. E. and Engelder, T.: Plate-scale stress fields driving the tectonic evolution of the central Ouachita salient, Oklahoma and Arkansas, Geol. Soc. Am. Bull., 118, 710-723, https://doi.org/10.1130/B25780.1, 2006.

Zhao, M. and Jacobi, R. D.: Formation of regional cross-fold joints in the northern Appalachian Plateau, J. Struct. Geol., 19, 817 834, https://doi.org/10.1016/S0191-8141(97)00009-6, 1997. 